\title{
Primates of the Cantanhez Forest and the Cacine Basin, Guinea-Bissau
}

\author{
Spartaco Gippoliti and Giacomo Dell'Omo
}

In a 4-week field study of the primates of Guinea-Bissau, a 10-day survey was carried out along the Cacine River and in the Cantanhez Forest to collect information about the presence of primates and other mammals. No biological information was available for these areas. The survey revealed the presence of at least seven primate species, four of which are included in the current IUCN Red List of Threatened Animals. Of particular interest was the West African chimpanzee Pan troglodytes verus. This was considered to be possibly extinct in Guinea-Bissau, but was found to be locally common. All primate species are particularly vulnerable because of uncontrolled exploitation of the forest, while hunting is responsible for the decline of game species in the area. Other rare species occur in the area and make the Cacine Basin and Cantanhez Forest a priority area for wildlife conservation at national and regional levels.

\section{Introduction}

Guinea-Bissau is a small country - 28,120 sq $\mathrm{km}$ - in coastal West Africa south of Senegal. While mangroves predominate on the coast, lowland forests of the Guinea-Congolian/ Sudanian transition zone (White, 1983) still cover small areas of the administrative sectors of Tombali and Quinara in the south-west of the country and the Cacheu region in the north west (Scott, 1992).

Until now, great efforts have been directed at the study and conservation of the internationally important coastal ecosystems, which are home to over 1 million wintering Palearctic waders (Altenburgh et al., 1992). Terrestrial ecosystems have been relatively neglected, perhaps because of the absence of endemic terrestrial vertebrates (Stuart and Adams, 1990). This has resulted in a lack of information about the distribution and population status of many taxa. As far as primates are concerned, the occurrence of some species still has to be confirmed (for example lesser white-nosed monkey Cercopithecus petaurista, potto Perodicticus potto and Demidoff's galago Galagoides demidoff [Oates, 1985]), and there is no available information about the population status of Temminck's red colobus Procolobus badius temminckii and the common chimpanzee Pan troglodytes. The latter was believed to be extinct in Guinea-Bissau (Lee et al., 1988; Scott, 1992), but in February-March 1988, during a previous visit to Guinea-Bissau, one of the authors (G.D.) collected evidence of chimpanzee presence in the south of the country.

The present survey was planned with the aim of obtaining reliable and recent evidence on the current population status and distribution of all primate species in Guinea-Bissau. During the survey, particular attention was devoted to the Cantanhez Forest in the south of the country, where two of the most endangered taxa were believed to occur: West African chimpanzee Pan troglodytes verus and Temminck's red colobus. P. t. verus is the most threatened of the three recognized subspecies of chimpanzee, with an estimated surviving population not exceeding 17,000 individuals (Lee et al., 1988; Teleki, 1989, but see Oates, [1994] for a critical analysis of this estimate). Recent genetic investigations have confirmed the validity of this subspecies (Morin et al., 1992), which appears to be the most divergent of the three recognized forms. Regrettably, considerable gaps still exist in the data 
concerning population distribution and density, and threats to the remaining scattered populations. Guinea, the (supposed) major stronghold of $P$.t. verus, has not been the subject of an extensive field survey since the 1960 s (de Bournonville, 1967). Chimpanzee populations are found in Sierra Leone, Liberia and Ivory Coast, while relict populations occur in Senegal, Mali and Ghana. The chimpanzee was believed to have been exterminated in six other countries, including Guinea-Bissau (Lee et al., 1988). P. b. temminckii is found only in Gambia, Senegal, Guinea-Bissau and northwest Guinea, and is the only red colobus subspecies restricted to the dry deciduous forest typical of the Guinean phytogeographical region and of the wetter areas of the Sudanian region (Booth, 1958; Gatinot, 1976). Although its distribution is relatively well known in Senegambia (Gatinot, 1974), nothing is known about its status in the other two countries. The location of the border between the range of $P$. $b$. temminckii and that of $P . b$. badius is unknown; our observations confirm that the red colobus occurring in southern Guinea-Bissau is a typical temminckii. Because the subspecies is considered 'Rare' by the IUCN (Lee et al., 1988), all information on this monkey is of great importance.

The Cantanhez Forest is a relatively large area encompassing more than $650 \mathrm{sq} \mathrm{km}$ in the administrative sectors of Tombali and Quinara (Figure 1). No detailed studies of the vegetation have yet been carried out. Scott (1992) described the close broadleaved forests of Guinea-Bissau as dominated by Afzelia africana, Alstonia congensis, Antiaris africana, Ceiba pentandra, Dialium guineense, Ficus spp. and Parinari excelsa. Rainfall in the study area is restricted to May-November, and does not usually exceed $1600 \mathrm{~mm}$ per annum. The forest can be better described as a savannahforest mosaic, with mangroves growing along the rivers and vast areas covered by terrestrial halophytic vegetation. Part of the Cantanhez Forest was classified as a hunting reserve by Law 21/1980 (Portas and Oliveira-Costa, 1985), which permanently banned hunting of all vertebrates. However, no protection for the forest is provided. Observations by long-term foreign residents confirm continuous agricultural encroachment on the reserve, particularly in the northern sector.

\section{Primate survey}

During a 4-week field study of the primates of Guinea-Bissau in 1994, a 10-day period, from 21 February to 2 March, was spent in the Cantanhez Forest. Direct observations were integrated with interviews with local inhabitants, who also helped the authors in the daily search for animals. The authors also used photographs and colour plates (Halternorth and Diller, 1980) to aid them in identifying primate and other mammal species. Observations were concentrated in an area south of the hunting reserve, starting from a campsite at Fazenda São Francisco da Floresta (c. $11^{\circ} 20^{\prime} \mathrm{N}-15^{\circ} 00^{\prime} \mathrm{W}$ ), on the west bank of the Dideregabi River, one of the western tributaries of the Rio Cacine. Walks were taken daily along beaten tracks, with frequent incursions into the forest. A forest inspection from the Dideregabi River was also conducted by boat.

During about $60 \mathrm{~h}$ of field observations in the area, six species of diurnal primates were observed. The savannah monkey Cercopithecus sabaeus (Dandelot, 1971) was observed only once, in a mangrove forest. As the local name, macaco de terrafe (mangrove monkey) indicates, its occurrence in the Cacine Basin appears to be limited to the mangrove areas, the same habitat in which the species was studied by Galat and Galat-Luong (1976) in southern Senegal. The other species of Cercopithecus most commonly observed in the study area was Campbell's monkey Cercopithecus campbelli campbelli. This subspecies, encountered 15 times in closed forest and woodland savannah, was sometimes observed eating acacia seeds on small isolated trees. Campbell's monkey does not hesitate to descend to the ground and is known to have a wide habitat tolerance (Harding, 1984; Oates, 1988). The narrow habitat preference of $C$. sabaeus, if confirmed, could be explained by competition with C. c. campbelli. Group size ranged from 20 
animals to a single monkey. No polyspecific association with other monkeys was observed, although local people reported that this species is frequently seen with the red colobus.

Temminck's red colobus and the western black-and-white colobus Colobus polykomos were encountered eight times each. In four cases they were observed in close association. A mixed group of the two colobines was observed only $500 \mathrm{~m}$ from the village of Jemberem feeding on a tree of Ceiba pentandra.
Although there are insufficient data to make generalizations, they suggest a tendency of the two to associate. Groups of Temminck's red colobus were estimated to consist of no fewer than 25-30 individuals and were found most commonly at heights of $20-30 \mathrm{~m}$ in large Parinari excelsa trees. Western black-and-white colobus groups were smaller, ranging from three to 10 individuals. In one instance, an isolated individual was also observed. The animals were commonly seen feeding at a height of only $8-10 \mathrm{~m}$ on Parinari trees. Only one

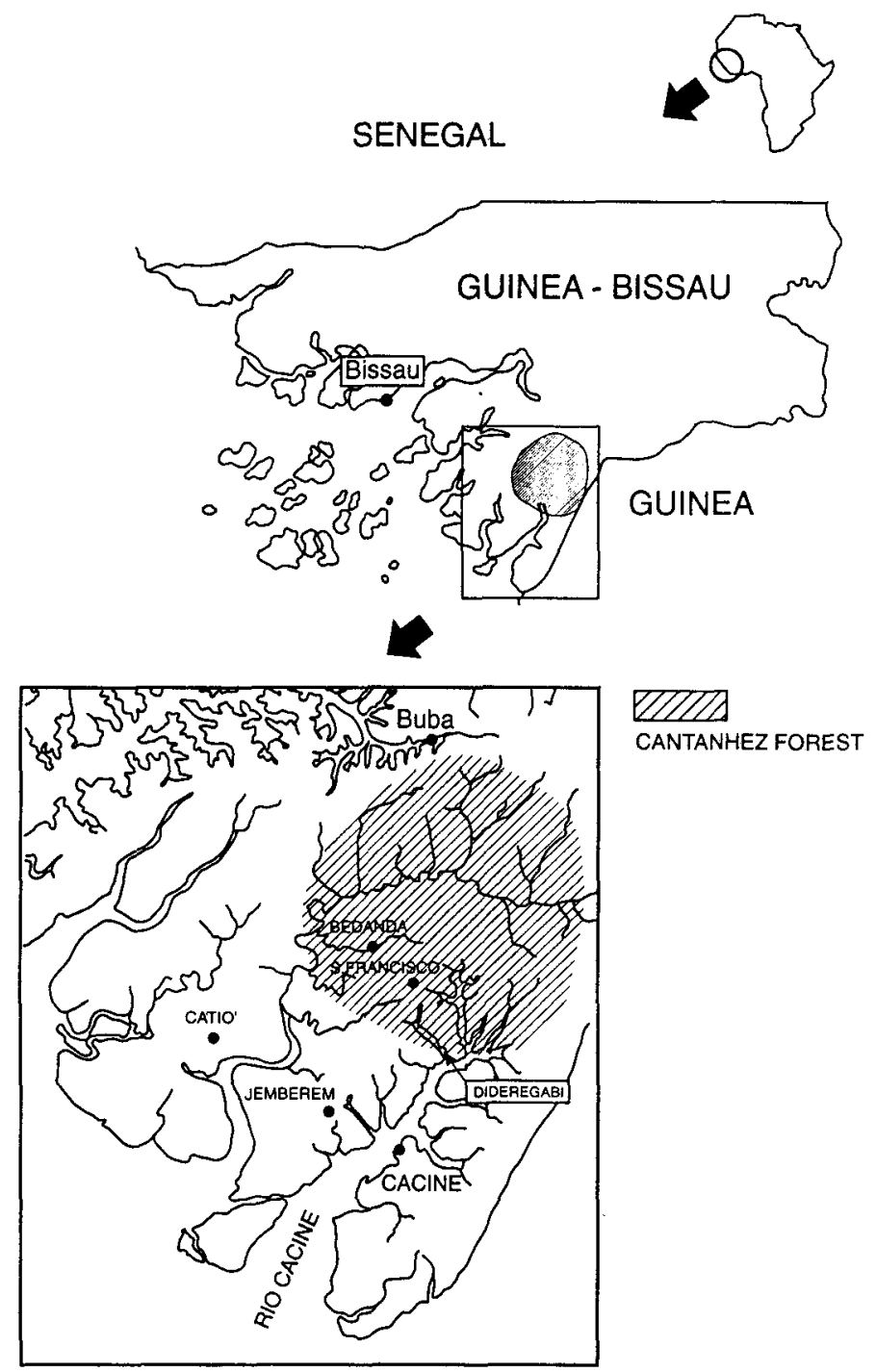

Figure 1. Maps showing the location of Catanhez Forest in Guinea-Bissau and the study area.

(C) $1996 \mathrm{FFI}$, Oryx, 30 (1), 74-80 
Table 1. Primates observed in the Cantanhez Forest

\begin{tabular}{ll}
\hline Galago senegalensis & $\begin{array}{l}\text { Western lesser } \\
\text { bushbaby } \\
\text { Campbell's monkey }\end{array}$ \\
$\begin{array}{l}\text { Cercopithecus campbelli } \\
\text { Cercopithecus sabaeus* }\end{array}$ & $\begin{array}{l}\text { Savannah monkey } \\
\text { Gapio papiot }\end{array}$ \\
Colobus polykomos & $\begin{array}{l}\text { Western black- } \\
\text { and-white colobus }\end{array}$ \\
Procolobus badius temminckii & $\begin{array}{c}\text { Temminck's red } \\
\text { colobus } \\
\text { Western chimpanzee }\end{array}$ \\
\hline
\end{tabular}

* sabaeus is considered distinct from aethiops in accordance with Dandelot (1971).

+ papio is considered a full species in accordance with Napier (1981).

typically white infant of this species was observed. The Guinea baboon Papio papio was observed five times in groups of 50-70 individuals, usually while moving on the ground along the main tracks. The animal's shyness made an exact count impossible. Although never observed directly, according to local hunters at least one member of the genus Galago (probably G. senegalensis) is present in the Cantanhez Forest. The potto Perodicticus potto is not known locally, and its presence may therefore be considered highly dubious in Guinea-Bissau.

\section{Chimpanzee}

We came into direct contact with chimpanzees on only two occasions. Two individuals were observed on trees during the boat survey and on another occasion a small group escaped into the closed forest emitting fear calls when we inadvertently approached too close. The most obvious signs of chimpanzee presence were their nests. All observed nests were made in the oil palm Elaeis guineensis, by folding the leaves toward the centre of the palm. Such nesting behaviour has never before been observed in any chimpanzee population studied so far (Baldwin et al., 1981). This unusual kind of nest, which we presume to be more durable than typical nests, prevented us from making a quantitative estimate of the chimpanzee population size from a nest count alone, as is usually done (Marchesi et al., 1992). At least 50 per cent of the observed palms showed signs of damage by chimpanzees. Vocalizations were also common signs of chimpanzee presence. In one day, the calls of three different groups were heard in a $3-\mathrm{km}$ radius from the Fazenda. According to our host and to subsequent investigations, seven different groups were in the area around the Fazenda. Such an apparently high density could be explained, however, by the presence of a permanent source of water in the area, which draws the animals from the surroundings during the dry season (when this survey was conducted). Vocalizations were heard and many nests observed along the road from São Francisco to Jemberem, which lies about $20 \mathrm{~km}$ to the south. Local residents confirm the presence of dari (as the chimpanzee is called in Guinea-Bissau) along the Jemberem-Catiò route. Catholic missionaries and volunteers also reported the presence of the species around Bedanda and Empada. Minor signs of the chimpanzee's presence were footprints along the tracks and food remains. The latter were once found in a small clearing where monkeys had been heard some hours before. They consisted of small piles of tambacumba (Terminalia macrophila) fruits.

To date, we have evidence of seven species of primates in the Cantanhez Forest (Table 1). Of the other three species that are definitely known to occur in Guinea-Bissau (Gippoliti and Dell'Omo, 1994), only the patas monkey Erythrocebus patas is clearly absent; its southern distribution boundary lies to the north of the Catanhez Forest. The lesser whitenosed monkey Cercopithecus petaurista buettikoferi has not been identified by local hunters, nor has the sooty mangabey Cercocebus atys atys. The apparent absence of the latter subspecies is particularly puzzling, because the only sighting of the species in the country came from Gadamael (Frade and Silva, 1980), not far from the study area.

\section{Other animals}

Mammals directly observed during the survey 
included: three species of duiker, Cephalophus rufilatus, C. maxwelli and C. silvicultor; the ground squirrel Heliosciurus gambianus; and two small carnivores, Atilax paludinosus and Viverra civetta. Field signs of the buffalo Syncerus caffer and the warthog Phacochoerus africanus were clearly evident. Species reported by local hunters include leopard Panthera pardus, serval Leptailurus serval, genet Genetta sp., cape clawless otter Aonyx capensis, red river hog Potamochoerus porcus, waterbuck Kobus ellipsyprimnus, bushbuck Tragelaphus scriptus and the flying squirrel Anomalurus beecrofti. The last three elephants were killed about 10 years ago (V. Bilego, pers. comm.). The manatee Trichechus senegalensis is occasionally reported in the Cacine River.

The Cacine Basin is an important area for the dwarf crocodile Osteolaemus tetraspis, a species whose status is largely unknown in Guinea-Bissau as well as in West Africa more generally (Thorbjarnarson et al., 1992).

\section{Discussion}

The Cantanhez Forest and the Cacine Basin have already been identified as critical sites for biodiversity conservation in Guinea-Bissau (Portas and Oliveira Costa, 1985; Chardonnet and Limoges, 1989; Stuart and Adams, 1990; Scott, 1992; IUCN, 1993). However, the idea of creating a national park in the area appears to be receiving little support at present.

The present survey, although preliminary, revealed additional conservation values of the region. The Cantanhez Forest not only contains the most western population of the endangered Pan troglodytes verus (Gippoliti and Dell'Omo, 1995) but is also the only area in which sympatry and polyspecific association between Procolobus badius temminckii and Colobus polykomos have been documented. The latter species is apparently absent from southern Senegal and Gambia (Struhsaker, 1971; Gatinot, 1974; Gunderson, 1977) and the red colobus is absent from the Kounounkan Forest, Guinea (Barnett et al., 1994), about 400 $\mathrm{km}$ south-east of the Cantanhez Forest.

Hunting is not a major problem for primates at present, although all diurnal species except chimpanzees are eaten by non-Muslim people. The same cannot be said for other animals; elephants and hippopotamus are locally extinct, while all large specimens of Nile crocodiles have disappeared. Until now chimpanzees have been protected because of their resemblance to humans, a belief also reported in Mali and Guinea (Moore, 1985; Sugiyama and Soumah, 1988). However, the selective poaching of female chimpanzees to obtain young for the live trade can have disastrous long-term effects on large and healthy populations of the species (Oldfield, 1992). Guinea-Bissau authorities could prevent such a problem from arising through stringent enforcement of existing national and international regulations. In contrast to what has been stated by DGFC/CECI/IUCN (1989), the red colobus should also be included among the fully protected species in the hunting law.

Destruction of forests by extensive and uncontrolled cutting of trees and starting fires is the major environmental problem of GuineaBissau and the red colobus, the most sensitive species to forest degradation, has already disappeared from large areas of the country. The FAO (1988) estimated that $170 \mathrm{sq} \mathrm{km}$ of closed broadleaved forest are lost each year. The absence of forest reserves in the country exacerbates this problem. Given the small size of Guinea-Bissau, the country's poverty and the widespread presence of a growing (mainly rural) population, a conservation strategy based mainly on the establishment of strictly protected areas seems unlikely to succeed. While a protected area would be an essential element in the protection of the southern region, particularly if it is adjacent to similar areas in bordering Guinea, further scientific research is urgently needed to determine the best way to implement a conservation strategy for the country. The Cantanhez Forest and the Cacine Basin can only be saved if a more holistic approach is attempted, addressing not only conservation issues but also the needs of local communities (Munasinghe and Wells, 1992). The participation of local rural communities through the legal right to manage at least part of the natural resources, as 
advocated by Ramberg (1993) and Happold (1995), seems to be the best long-term approach to reconcile wildlife conservation and rural development. For example, ecotourism has not yet been developed in Guinea-Bissau and small-scale tourist programmes in the area could help emphasize the importance of the primates and could also boost the local economy.

\section{Acknowledgements}

The authors are grateful to R. Mittermeier and G. Teleki for encouraging and supporting our mission, to P. Campredon and B. Paris for their kind assistance and advice in Guinea-Bissau. V. Bilego deserves special thanks for sharing his knowledge of Cantanhez Forest with us. Thanks are also due to all the missionaries and volunteers encountered during the survey.

\section{References}

Altenburg, W., Wymenga, E. and Zwarts, L. (eds) 1992. Ornithological Importance of the Coastal Wetlands of Guinea-Bissau. WIWO Report No. 26.

Baldwin, P.J., Sabater, P.J., McGrew, M.C. and Tutin, C.E.G. 1981. Comparisons of nests made by different populations of chimpanzees (Pan troglodytes). Primates, 22, 474-486.

Barnett, A., Prangley, M., Hayman, P.V., Diawara, D. and Koman, J. 1994. A preliminary survey of Kounounkan Forest, Guinea, West Africa. Oryx, 28, 269-275.

Booth, A.H. 1958. The zoogeography of West African primates: a review. Bulletin Institut Français d'Afrique Noire, A 20, 587-622.

de Bournonville, D. 1967. Le chimpanzé en République de Guinée. Bulletin de l'Institut Fondamental d'Afrique Noire, 29A, 1188-1269.

Chardonnet, P. and Limoges, B. 1989. GuineaBissau. In Antelopes: Global Survey and Regional Action Plans. Part 3. West and Central Africa (ed. R. East), pp 35-37. IUCN, Gland, Switzerland.

Dandelot, $_{,}$P. 1971. Classification of African Anthropoidea. In The Mammals of Africa: An Identification Manual (eds J. Meester and H.W. Setzer.). Smithsonian Institution Press, Washington, DC.

DGFC/CECI/IUCN 1989. Resultats de l'inventaire faunistique au niveau national et propositions de modification de la loi sur la chasse. DGFC/CECI/IUCN, Bissau.

FAO. 1988. An Interim Report on the State of Forest Resource in the Developing Countries. FAO, Rome.
Frade, F. and Silva, J.A. 1980. Mamiferos da Guiné (colecção do Centro de Zoologia). Garcia de Orta, Sér. Zool. 9, 121-149.

Galat, G. and Galat-Luong, A. 1976. La colonisation de la mangrove par Cercopithecus sabaeus au Senegal. La Terre et la Vie, 30, 3-30.

Gatinot, B.L. 1974. Précisions sur la répartition du Colobe bai (Colobus badius temminckii, Kuhl 1820) et de la Mone de Campbell (Cercopithecus mona campbelli, Waterhouse 1838) en Sénégambia. Mammalia, 38, 711-716.

Gatinot, B.L. 1976. Les milieux fréquentés par le colobe bai d'Afrique de l'Ouest (Colobus badius temminckii Kuhl, 1820) en Sénégambia. Mammalia, 40, 1-12.

Gippoliti, S. and Dell'Omo, G. 1994. Primati della Guinea-Bissau (Africa Occidentale). Distribuzione e priorità per la conservazione. $I^{\circ}$ Congresso Italiano di Teriologia, Pisa, 27-29 October 1994. Abstract book, 175.

Gippoliti, S. and Dell'Omo, G. 1995. Status and conservation of Western chimpanzee Pan troglodytes verus in Guinea-Bissau. African Primates, 1, 3-5.

Gunderson, V. 1977. Some observations on the ecology of Colobus badius temminckii, Abuko Nature Reserve, The Gambia, West Africa. Primates, 18, 305-314.

IUCN, 1993. Planificação costiera, Guinée-Bissau Relatòrio Técnico. IUCN, Bissau.

Haltenorth, T. and Diller, H. 1980. A Field Guide to the Mammals of Africa including Madagascar. Collins, London.

Happold, D.C.D. 1995. The interactions between humans and mammals in Africa in relation to conservation: a review. Biodiversity and Conservation, 4, 395-414.

Harding, R.S. 1984. Primates of the Kilimi area, Northwest Sierra Leone. Folia Primatologica, 42, 96-114.

Lee, P.C., Thornback, J. and Bennett, E.L. 1988. Threatened Primates of Africa: The IUCN Red Data Book. IUCN, Gland, Switzerland.

Marchesi, P., Marchesi, N. and Boesch, C. 1992. Census and distribution of chimpanzees in Côte d'Ivoire. Bulletin Chicago Academy of Sciences, 15, 31-32.

Moore, J. 1985. Chimpanzee survey in Mali, West Africa. Primate Conservation, 6, 59-63.

Morin, P.A., Moore, J.J. and Woodruff, D.S. 1992. Identification of chimpanzee subspecies with DNA from hair and allele-specific probes. Proceedings Royal Society London, B. 249, 293-297.

Munasinghe, M. and Wells, M. 1992. Protection of natural habitats and sustainable development of local communities. In Conservation of West and Central African Rainforests (eds K. Cleaver, M. Munasinghe, M. Dyson, N. Egli, A. Peuker and F. 
Wancélius), pp. 161-168. World Bank Environment Paper, No. 1. World Bank, Washington, DC.

Napier, P.H. 1981. Catalogue of Primates in the British Museum (Natural History) and elsewhere in the British Isles. Part II: Family Cercopithecidae, subfamily Cercopithecinae. British Museum (Natural History), London.

Oates, J.F. 1985. Action Plan for African Primates Conservation: 1986-1990. IUCN, Gland, Switzerland.

Oates, J.F. 1988. The distribution of Cercopithecus monkeys in West African forests. In A Primate Radiation: Evolutionary Biology of the African Guenons (eds A. Gauthier-Hion, F. Bourlière, J.-P. Gauthier and J. Kingdom), pp. 79-103. Cambridge University Press, Cambridge.

Oates, J.F. 1994. Africa's primates in 1992: conservation issues and options. American Journal of Primatology, 34, 61-71.

Oldfield, M.L. 1992. Impact on West African chimpanzee populations of poaching for the live trade. Bulletin Chicago Academy of Sciences, 15, 29.

Portas, P. and Oliveira-Costa, J.P. 1985. GuinéeBissau: vers l'élaboration d'une strategie nationale de conservation des resources naturelles. IUCN, Gland, Switzerland.

Ramberg, L. 1993. African communities in conservation: A humanistic perspective. Revue de Zoologie Africaine, 107, 5-18.

Scott, J. 1992 Guinea-Bissau. In The Conservation Atlas of Tropical Forests: Africa (eds J. A. Sayer, C.
S. Harcourt and N.M. Collins), pp. 200-205 McMillan, London.

Struhsaker, T.T. 1971. Notes on Cercocebus a. atys in Senegal, West Africa. Mammalia, 35, 343-344.

Stuart, S.N. and Adams, R.J. 1990. Biodiversity in Sub-Saharan Africa and its Islands: Conservation, Management and Sustainable Use. Occasional Papers of the IUCN Species Survival Commission No. 6. IUCN, Gland, Switzerland.

Sugiyama, Y. and Soumah, A.G. 1988. Preliminary survey of the distribution and population of chimpanzees in the Republic of Guinea. Primates, 29, 569-574.

Teleki, G. 1989. Population status of wild chimpanzees (Pan troglodytes) and threats to survival. In Understanding Chimpanzees (eds G. Heltne and L. Marquard), pp. 312-352. Harvard University Press, Cambridge.

Thorbjarnarson, J., Messel, H., King, F.W. and Ross, J.P. 1992. Crocodiles: A Plan for their Conservation. IUCN, Gland, Switzerland.

White, F. 1983. The Vegetation of Africa. UNESCO, Paris.

Spartaco Gippoliti, Viale Liegi 48A, 00198 Rome, Italy.

Giacomo Dell'Omo, Monks Wood Institute for Terrestrial Ecology, Abbots Ripton, Huntingdon, Cambridgeshire PE17 2LS, UK. 